\title{
The Influence of Bilateral Treaties with Third States on Jurisdiction and Recognition of Decisions in Matters on Succession - Polish Perspective
}

\begin{abstract}
The aim of the study is to discuss the impact of bilateral international treaties concluded by EU Member States with third countries on jurisdiction and recognition of judgments in matters of succession from Polish perspective. The author discusses the main problems in the interpretation of Article 75 of Regulation 650/2012 and the possible conflict of this solution with the Treaty on the Functioning of the EU. The article indicates also practical problems related to the collision of bilateral treaties and Regulation No 650/2012 regarding, for example, the possibility of concluding choice-of-court agreements, recognition of foreign judgments in matters of succession and the possibility of issuing the European Certificates of Succession.
\end{abstract}

Keywords: bilateral treaties - Regulation (EU) No 650/2012 - inheritance proceedings - international jurisdiction - recognition and enforcement of decisions in matters of succession

\section{Introduction}

The purpose of Regulation (EU) No 650/2012 was to unify completely the regulations concerning, among other things, international jurisdic-

a) Dr hab., University of Warsaw. 
tion and the recognition and enforcement of decisions in matters of succession within the European Union. The same applied to conflict-of-laws rules in those matters. For that reason, the jurisdiction provisions in the Regulation, for example, exclude, as a rule, the possibility of invoking jurisdiction grounds in the succession matters, which the Court of Justice explicitly confirmed in its judgment in re: Oberle $^{1}$.

Nevertheless, Regulation (EU) No 650/2012 provided for an exception to that rule in case of bilateral international agreements (treaties) with third countries on succession matters that had been made before the effective date of the Regulation (Article 75.1 of Regulation (EU) No 650/2012). On the one hand, that was supposed to keep the existing international obligations of Member States towards third countries. ${ }^{2}$ On the other hand, the Regulation has completely replaced bi- and multilateral agreements between Member States, except for the Hague Convention of 1961 and the Nordic Convention (Article 75.2 of Regulation (EU) No 650/2012).

The solution gives rise to many concerns in Poland as there is a considerable number of bilateral agreements that Poland had undertaken prior to its accession to the EU and that regulate the direct international jurisdiction of courts as well as the recognition and enforcement of decisions in the succession matters ${ }^{3}$. The provisions to that effect are typically included in bilateral agreements on judicial cooperation in civil matters and there are more than thirty such agreements to which Poland is a party. As there has been a large number of citizens from Ukraine, Belarus, and Russia migrating to Poland recently, the provisions of agreements with those countries are of particular importance in that context ${ }^{4}$. Notably: Agreement between the Republic of Poland and the Republic of Belarus on legal aid and legal relationships in civil, family, labour, and

${ }^{1}$ Judgment of the CJEU of 21 June 2018 in case C-20/17, proceedings brought by Vincent Pierre Oberle.

${ }^{2}$ A. Bonomi: Le droit des successions. Commentaire du Reglement (UE) no 650/2012 du 4 julliet 2012. Bruylant 2016, p. 939.

${ }^{3}$ Cf. among others, P. Czubik: Obowiazywanie norm kolizyjnych z umów o pomocy prawnej zawartych $z$ Białorusia, Ukraina $i$ Rosja $w$ obrębie materii objętej zakresem zastosowania rozporzadzeń europejskich. „Nowy Przegląd Notarialny” 2015, No. 3, pp. $19 \mathrm{ff}$.

${ }^{4}$ M. Margoński also points to the practical importance of the agreement with Vietnam (in: Rozporzqdzenie Parlamentu Europejskiego i Rady (UE) Nr 650/2012 z dnia 4 lipca 2012 r. w sprawie jurysdykcji, prawa wtaściwego, uznawania $i$ wykonywania orzeczeń, przyjmowania $i$ wykonywania dokumentów urzędowych dotyczacych dziedziczenia oraz $w$ sprawie ustanowienia europejskiego poświadczenia spadkowego. Komentarz. Ed. K. Osajda. Warszawa 2020, comment 10 on Article 75). 
criminal matters, concluded on 26 October 19945; Agreement between the Republic of Poland and the Russian Federation on legal aid and legal relationships in civil and criminal matters, concluded on 16 September $1996^{6}$ and Agreement between the Republic of Poland and Ukraine on legal aid and legal relationships in civil and criminal matters, concluded on 24 May 19937. As regards jurisdiction-related provisions, the agreements contain identical regulations concerning the recognition and enforcement of decisions.

Naturally, the problem is more complex as similar agreements were signed by West European countries (agreements between Germany and Iran, Russia and Turkey; Austria and Iran and Russia; France and Iran, Cambodia and Tunisia) as well as other Central and Eastern European countries (Estonia, Lithuania, Latvia with Russia and Ukraine) ${ }^{8}$. However, in Poland the problem is quite specific as the agreements do include regulations on direct jurisdiction in matters of succession, rather than only being limited in scope to the applicable law ${ }^{9}$.

The issue at hand not only pertains to the relations between the said agreements and procedural rules concerning jurisdiction, recognition, and enforcement of decisions, but also to conflict-of-laws regulations included in the agreements. Yet, those issues are beyond the scope of this paper.

\section{The wording and the origin of Article 75.1 of the Regulation}

In keeping with Article 75.1 of Regulation (EU) No 650/2012 the said Regulation shall not affect the application of international conventions to which one or more Member States are party at the time of adoption of that Regulation and which concern matters covered by that Regulation.

${ }^{5}$ Journal of Laws of 1995 No. 128, item 619.

${ }^{6}$ Journal of Laws of 2002 No. 83, item 750.

7 Journal of Laws of 1994 No. 96, item 465.

${ }^{8}$ Cf. the list of agreements presented by R. Frimston: European Union Succession Regulation 650/2012: an update end entreaty. "Private Client Business" 2018, vol. 6, p. 198.

${ }_{9}^{9}$ R. Frimston: European Union Succession Regulation..., p. 198, who points out that the Western countries regulated international jurisdiction issues only in agreements with Turkey. 
The provision contains the so-called compatibility clause that is also present in other regulations, such as: Article 73.3 of Regulation (EU) No 1215/2012 (Brussels IA), Article 25.1 of Regulation (EC) No 593/2008 (Rome I) and Article 28.1 of Regulation (EC) No 864/2007 (Rome II).

It is a known fact that the lack of explicit compatibility clause in Regulation (EC) No 44/2001 (Brussels I) that preceded Regulation (EU) No 1215/2012 was the subject of disputes in the doctrine ${ }^{10}$. The regulation contained in Regulation (EC) No 44/2001 which defined its relations with other instruments (Articles 67 to 72) was incomplete as it did not cover the relations between Regulation (EC) No 44/2001 and international agreements that are binding on Member States and third countries and that are not international agreements on particular matters, as referred to in Article 71 of Regulation (EC) No 44/2001, and agreements referred to in Article 72 of Regulation (EC) No 44/200111. In practice it referred to bilateral agreements between Member States and third countries. Therefore, the issue at stake was the mutual relation between Regulation (EU) No 44/2001 and specific international agreements with third countries which was of importance when a specific international agreement contained regulations concerning direct international jurisdiction. To make it as simple as possible, the issue came down to the question whether or not, in a case which is subject to both Regulation (EC) No 44/2001 and an international agreement with a third state, the court in a Member State forum should follow the provisions of Regulation (EC) No 44/2001 or the provisions of the international agreement.

The said issue of the mutual relation between Regulation (EU) No 44/2001 and specific international agreements with third countries gave rise to concerns. Some claimed that the conflicts of law arising in such a situation should be resolved in such a way as to keep the provisions of the international agreement with a third state intact ${ }^{12}$, which usually means that the provisions of the agreement prevailed over the provisions of Regulation (EC) No 44/2001; others claimed that Regulation (EC) No 44/2001 also prevailed over international agreements of

${ }^{10}$ Cf. P. Mankowski, in: Brussels I Regulation. Eds. U. Magnus, P. Mankowski, Sellier 2007, pp. 760-761.

11 See A. Nuyts: Study of Residual Jurisdiction: Review of the Member States' Rules concerning the 'Residual Jurisdiction' of their courts in Civil and Commercial Matters pursuant to the Brussels I and II Regulations'. Available online: https://gavclaw. files.wordpress.com/2020/05/arnaud-nuyts-study_residual_jurisdiction_en.pdf (accessed 13.10.2020), p. 146.

${ }^{12}$ Cf. P. Grzegorczyk: Jurysdykcja krajowa w sprawach z zakresu prawa własności przemysłowej, Warszawa 2007, pp. 140-141; R. Geimer, in: R. Geimer, R.A. Schütze: Europäisches Zivilverfahrensrecht: EuZVR. 3 Aufl. C.H. Beck, München 2010, Art. 71, bibliographic note 18, p. 895 (citing Article 71 of Regulation No 44/2001). 
Member States with third countries ${ }^{13}$. The latter standpoint relied on the assumption that Regulation (EC) No 44/2001 was of universal nature and that the national law of Member States and their international agreements with third countries are applied only under Article 4.1 of Regulation (EC) No 44/2001 if the defendant had no domicile or registered office in any Member State. As a result, where the scopes of application of Regulation (EC) No 44/2001 and of the said international agreements coincided, the said agreements could not be applied pursuant to Article 4.1 of Regulation (EC) No 44/2001. In that context, the fact that the provisions specifying the relation between Regulation (EC) No 44/2001 and other instruments do not contain a rule concerning such agreements was supposed to mean that Regulation (EC) No 44/2001 was to be applied rather than such international agreements.

Due to the expansion of the scope of application of Regulation (EU) No 1215/2012 so as to include defendants from countries other than EU countries, the EU legislator decided to regulate clearly the relations between Regulation and bilateral agreements in Article 73.3, even though such a solution had not originally been included in the proposed regulation. It was only included after attracting criticism from the doctrine. Consequently, as far as jurisdiction in civil and commercial matters is concerned, a solution parallel to the one previously established in the area of conflicts-of-laws regulations under Article 25.1 of Regulation (EC) 593/2001 (Rome 1) and Article 28.1 of Regulation (EC) 864/2007 started to be applied. Upon the adoption of such a solution, in case of a conflict between an EU jurisdiction regulation and a jurisdiction regulation (concerning direct international jurisdiction) in an international agreement between Poland and a third state, the jurisdiction regulation in said international agreement would have a priority as a rule. Such priority is naturally delineated by the limits on the application of the international agreement with a third state and it only applies to the subject matter of the regulation; most significantly, in addition to regulating direct jurisdiction it could also cover other jurisdiction-related issues (e.g. examination as to jurisdiction, respecting prior lis pendens of the case), as long as a given international agreement contains some provisions in that respect.

${ }^{13}$ See the report by A. Nuyts: Study..., p. 147 citing the ECJ opinion of 7.02.2006, 1/03 (ECR 2006, p. I-01145) concerning the projected conclusion of the Lugano Convention II. The same direction is also followed by P. Grzebyk: Jurysdykcja krajowa w sprawach z zakresu prawa pracy $w$ świetle rozporzadzenia Rady (WE) $n r$ 44/2001. Warszawa 2011, pp. 56-57. The author refers to a situation where the international agreement with a third state contains the so-called compatibility clause, as a result of which priority should be given to Regulation (EC) No 44/2001. 
It seems that similar arguments were considered when adopting Article 75.1 of Regulation (EU) No 650/2012 as a legal instrument regulating not only procedural rules but also conflicts-of-laws rules. Therefore, the adopted interpretation of Article 73.3 of Regulation (EU) 1215/2012 cannot be disregarded when interpreting Article 75.1 of Regulation (EU) No 650/2012.

\section{Problems with the application of Article 75.1}

\section{a) Conflict with Article 351 of TFEU}

The doctrine pointed out that the consequences of introducing a compatibility clause concerning international agreements with third countries should also be viewed from the perspective of Article 351 of the Treaty on the functioning of the European Union (TFEU) ${ }^{14}$. On the one hand, Article 351.1 of TFEU reads that TFEU shall not affect the rights and obligations of Member State arising from agreements with third countries concluded before 1 January 1958 or, for acceding States, before the date of their accession; on the other hand, Article 351.2 of TFEU provides that to the extent that such agreements are not compatible with TFEU (which also includes incompatibility with secondary EU law), the Member State concerned shall take all appropriate steps to eliminate the incompatibilities established. It is assumed that the duty may involve the need to renegotiate, or even terminate, an agreement with a third state, unless it is impossible under the provisions of the said agreement and of international $\operatorname{law}^{15}$. The question arises how to evaluate, under Article 351.2 of TFEU, the compatibility clauses existing in secondary laws, such as: Article 73.3 of Regulation (EU) No 1215/2012 (Brussels IA),

${ }^{14}$ Cf. Ch. Kohler: Die künftige Erbrechtsverordnung der Europäischen Union und die Staatsverträge mit Drittstaaten. In: Europäisches Erbrecht. Zum Verordnungsvorschlag der Europäischen Kommission zum Erb- und Testamentsrecht. Eds. G. Reichelt, W.H. Rechberger, 2011, p. $109 \mathrm{ff}$.

${ }_{15}$ On Article 351 TFEU (former Article 397 of EC Treaty) see K. Schmalenbach, in: EUV/EGV. Das Verfassungsrecht der Europäischen Union mit Europäischer Grundrechtecharta. Kommentar. Eds. Ch. Calliess, M. Ruffert, München 2007, art. 307, pp. 2460-2467; D. Booß, in: EU-Verträge. Kommentar nach dem Vertrag von Lissabon. Eds. C.-O. Lenz, K.-D. Borchardt. Köln-Wien 2010, art. 351, pp. 2882—2885; D.-E. Khan, in: EUV/AEUV. Vertrag über die Europäische Union und Vertrag über die Arbeitsweise der Europäischen Union. Kommentar. Eds. R. Geiger, D.-E. Khan, M. Kotzur. München 2010, art. 351, pp. 967-970. 
Article 25.1 of Regulation (EC) No 593/2008 (Rome I) and Article 28.1 of Regulation (EC) No 864/2007 (Rome II), and most of all Article 75.1 of Regulation (EU) No 650/2012. Two lines of thoughts seem possible in this case.

First of all, it may be claimed that since a given instrument of secondary law explicitly provides that an international agreement has priority over its provisions, including an agreement between a Member State or Member States and a third state or third countries, then such an international agreement is not incompatible with that instrument of secondary law, therefore there is no incompatibility within the meaning of Article 351.2 of TFEU ${ }^{16}$.

Secondly, it may be argued that no compatibility clause may repeal the effect of Article 351.2 of TFEU, therefore even if such a clause is added to a given secondary law instrument, the fact will not alter the duties of the Member States under that regulation.

If the former standpoint is adopted, then some importance would need to be ascribed to the language of the compatibility clause itself. See for example the language of Article 69.1 of Regulation (EC) 4/2009, which reads that while the Regulation shall not affect the application of bilateral conventions and agreements to which one or more Member States are party and which concern maintenance matters, the obligations of the Member States under Article 351 of TFEU (former Article 307 of the EC Treaty) remain valid. There is no such reservation under Article 73.3 of Regulation (EC) No 1216/2001, Article 25.1 of Regulation (EC) No 593/2008 (Rome I) and Article 28.1 of Regulation (EC) No 864/2007 (Rome II) and Article 75.1 of Regulation (EU) No 650/2012. Therefore, as a result of that provision, bilateral agreements keep their priority over the Regulation.

If the latter standpoint is adopted, countries such as Poland would be required to terminate bilateral agreements with third countries within the scope overlapping with the scope of Regulation (EU) No 650/2012. However, it is hard to accept that standpoint because bilateral agreements are used to set a certain standard of protection in both contracting states. It is therefore not advisable for Poland to voluntarily eliminate the duty for a third state to apply specific contractual provisions to Polish nationals in that country. Such a step could lead to considerable deterioration of the standard of protection afforded to Polish citizens or the predictability of decisions made by the authorities of the third state.

${ }^{16}$ Cf. Opinion of the Legal Service of 7.02.2000 in conjunction with Article 64 of the subsequent Regulation (EC) No 44/2001 (5353/00) and Opinion of the Legal Service of 22.03.2006 in conjunction with Article 28 of the subsequent Regulation (EC) No 864/2007 (Rome II) (7645/06). Also in A. Bonomi: Le droit des successions..., p. 938. 
Termination of certain provisions regulating certain issues (such as conflicts-of-laws standards, rules of recognising foreign decisions) might, however, be possible but they should not be terminated altogether ${ }^{17}$.

b) Compatibility clause under Article 75.1 vs compatibility clauses in international agreements

The views presented in the doctrine include an opinion that due to a "general compatibility clause" in the agreements between Poland and Belarus, Russia and Ukraine, the Succession Regulation has priority over those bilateral conventions ${ }^{18}$. Under Article 105 of the agreement with Belarus, Article 102 of the agreement with Russia and Article 97 of the agreement with Ukraine, the agreements do not affect the provisions of other agreements binding on one or both contracting parties.

However, this is a minority opinion. The critics raised, however, that Article 75.1 of Regulation (EU) No 650/2012 was disregarded and it prevented conflict between the Regulation and the conventions signed with countries other than EU Member States in that they remain in full force and effect in terms of the substance covered thereby. In addition, it is also mentioned that the scope of the said conventions is very narrow. They cover actual states of affairs that are strongly related to the legal areas of the countries being parties to specific conventions. The solutions adopted in the conventions rely on the principle that similar matters should be treated in the same manner in both countries ${ }^{19}$. The key argument being that compatibility clauses in agreements binding on Poland may be applied only to obligations existing at the time they are concluded and not in the future in respect of other obligations. ${ }^{20}$ Furthermore, they only relate to conflicts with other agreements, rather than the provisions of internal law, that is the provisions of regulations once they have been adopted by EU authorities.

${ }^{17}$ Cf. P. Czubik: Obowiazywanie..., pp. 26-27. The author postulates termination of all conflicts-of-laws regulations under agreements on judicial cooperation.

${ }_{18}$ According to M. Czepelak in such a case it should be assumed that the compatibility clauses are mutually waived, and therefore priority should be given to the EU regulation. See in respect to Article 25 of Regulation (EC) No 593/2008 and Article 28 of Regulation (EC) No 864/2007, M. Czepelak: Umowa międzynarodowa jako źródto prawa prywatnego międzynarodowego. Warszawa 2008, pp. 377-378.

${ }_{19}$ M. Pazdan: Zakres zastosowania rozporzadzenia spadkowego. In: Nowe europejskie prawo spadkowe. Eds. M. Pazdan, J. Górecki. Warszawa 2015, item 4.

${ }_{20}$ M. Szpunar, K. Pacuła: Prawo prywatne międzynarodowe. Komentarz. Ed. M. Pazdan. Warszawa 2019, bibliographic note C.2 on Article 75 of Regulation (EU) No 650/2012, legalis. 


\section{Provisions of bilateral agreements binding in Poland}

As regards jurisdiction-related provisions, the agreements binding on Poland use nationality as the connecting factor and location as the connecting factor for immovable property. In keeping with Article 41.1 of the agreement with Ukraine, Article 42.1 of the agreement with Russia, and Article 45.3 of the agreement with Belarus, succession matters concerning movable property shall be within jurisdiction of authorities of the party of which the testator was citizen at the time of death. According to the second paragraph of those articles, succession matters concerning immovable property shall be resolved by authorities of the party where the property is situated. In addition, all three agreements envisage the possibility of referring the case to the other country if the entire movable property left upon the death of a citizen of one party remains on the territory of the other party, provided an heir makes such a request and all known heirs give their consent thereto (Article 41.3 of the agreement with Ukraine, Article 42.3 of the agreement with Russia and Article 45.3 of the agreement with Belarus). The agreements do not provide for the possibility of entering into agreements on national jurisdiction of Polish courts.

All three agreements also provide for a mechanism for the recognition and declaration of enforceability of decisions in civil cases which also include decisions in succession matters. They regulate the proceedings on recognition and declaration of enforceability of decisions from the country of the other party, as well as the grounds for refusal of recognition or enforcement of decisions. However, they do not provide for automatic recognition of decisions which has been known in the EU for many years, ever since the Brussels Convention of 1968; in contrast, they require proceedings in that matter while reserving that the law of the contracting party in which the decision is to be recognised and enforced shall apply to the decision recognition and enforcement.

\section{Problematic issues in the application of bilateral agreements}

First of all, there are concerns as to which issues should be considered within the scope of the agreement and which ones should be deemed 
to fall outside the scope. It is therefore about the interpretation of Article 75.1 and determining the exclusion of the Regulation application within the scope that coincides with the scope of the agreement. As regards jurisdiction, recognition, and enforcement of decisions and documents, other than decisions, legitimising heirs, the scope of the Regulation is much broader than that of bilateral agreements.

It seems that since agreements regulate the grounds of international jurisdiction of the courts of both countries, then a Polish court may not invoke the Regulation as the grounds of its jurisdiction if the testator was a citizen of a country subject to the agreement, even if his/her last place of domicile was in an EU Member State. That also applies to a situation where jurisdiction would only by justified by the fact that assets were left in a Member State. Therefore, the application of Articles 4 and 10 of Regulation (EU) No 650/2012 by a Polish court is excluded. It is, however, worth keeping in mind that the said agreements are only binding on Poland - consequently, from the perspective of other courts of Member States Polish courts have national jurisdiction under Article 4 of Regulation (EU) No 650/2012 in a succession matter involving, for example, a deceased Ukrainian citizen who had his habitual residence in Poland at the time of death ${ }^{21}$. However, there are opinions that in such a situation the court of another Member State should take into account a bilateral agreement binding on the other Member State ${ }^{22}$. However, that position is doubtful.

The question is whether or not it is possible to effectively enter into a jurisdiction agreement in such a matter pursuant to the regulation. Bilateral agreements do not provide for the possibility of entering into jurisdiction agreements although they do not explicitly prohibit it. Given the time when those agreements had been made, it should be concluded that such a possibility was excluded at that time. Obviously it is first necessary to answer the question whether or not a Ukrainian, Russian, or Belarussian citizen who has habitual residence in Poland may choose the law to govern his/her succession under Article 22 of Regulation (EU) No 650/2012 ${ }^{23}$. That is because the conflicts-of-laws rules under the bi-

${ }^{21}$ See M. Margoński, in: Rozporzqdzenie Parlamentu Europejskiego i Rady (UE) Nr 650/2012 z dnia 4 lipca 2012 r. w sprawie jurysdykcji, prawa właściwego, uznawania $i$ wykonywania orzeczeń, przyjmowania $i$ wykonywania dokumentów urzędowych dotyczacych dziedziczenia oraz $w$ sprawie ustanowienia europejskiego poświadczenia spadkowego. Komentarz. Ed. K. Os ajda. Warszawa 2019, comment 14 on Article 75, Legalis.

${ }^{22}$ R. Frimston's position in R. Frimston: European Union Succession Regulation..., p. 199, can also be interpreted in that way.

${ }^{23}$ This refers to the law of a Member State, in keeping with Article 6. In practice, it applies to individuals who changed citizenship before death or who have dual citizenship. 
lateral agreements do not allow that either. Choice of law is the premise for entering into a choice-of-court agreement. It seems that the opinion currently prevailing in Poland is that it is impossible. Consequently, it is considered that using a choice-of-court agreement as the basis for the jurisdiction of Polish courts in succession matters involving citizens of countries being parties to bilateral agreements is ineffective.

However, those issues are highly disputable as the bilateral agreements binding on Poland do not create a complete jurisdiction mechanism for succession matters. They do not regulate many material issues not only in terms of choice-of-law agreements, but also in terms of examination as to jurisdiction, effects of declining jurisdiction, etc. In the latter scope, Regulation (EU) No 650/2012 should definitely be applicable.

There are also concerns as to whether or not a Polish court may use Article 11 of Regulation (EU) No 650/2012 (Forum Necessitatis) as the grounds for its jurisdiction if such a solution is not envisaged under agreements binding on Poland. It seems, however, that since forum necessitatis is applied when courts of the other country have no jurisdiction or it is impossible to effectively initiate proceedings before the competent court, then such a possibility should be permitted pursuant to the Regulation $^{24}$. Besides, if there had been no grounds for the application of Regulation (EU) No 650/2012, then the Polish court would still have to take advantage of forum necessitatis as regulated under Polish law (Article $1099^{1}$ of the Polish Code of Civil Procedure).

There are also important issues concerning the recognition and enforcement of decisions in succession matters.

First of all, the Regulation provisions concerning the proceedings on the recognition and declaration of enforceability only apply to decisions originating from Member States that follow the Regulation. Therefore, they do not apply to decisions on succession matters originating from third countries. That creates problems in a situation where the court of a Member State gave its decision on a succession while using the Regulation as the grounds of its jurisdiction or for determining the applicable law, even though a bilateral agreement should be applied in a given case from the Polish perspective. As rightly noted in the doctrine, under such circumstances the Polish court has no grounds to refuse to recognise such a decision because it is not envisaged in any grounds of non-recognition under Article 40 of Regulation (EU) No 650/2012 ${ }^{25}$. The Regulation

${ }^{24}$ A. Dutta: Münchener Kommentar, Vol. 10 (ed. J. v. Hein), Article 64 of Regulation (EU) No 650/2012, Article 64 of Regulation (EU) No 650/2012, bibliographic note 9; M. Margoński, in: Rozporzqdzenie..., bibliographic note 16 on Article 75.

${ }_{25}$ M. Margoński, in: Rozporzqdzenie..., bibliographic note 21 on Article 75. 
does not provide for any control in terms of conflict of laws or jurisdiction in respect of decisions subject to recognition.

It should be also pointed out, as a side note, that the grounds for nonrecognition of decisions under agreements with Ukraine, Russia, and Belarus do not include a public policy clause. It is quite surprising because such a ground was left in Regulation (EU) No 650/2012 for succession decisions from EU and also in other EU regulations concerning recognition and enforcement of decisions. This means that decisions from third countries receive preferential treatment versus the decisions of courts from EU Member States which are subject to control in terms of the public policy clause. It gives rise to reasonable concerns and the question as to whether or not the public policy clause should be added to the grounds of non-recognition for decisions originating from third countries. However, that would require either the relevant interpretation of the bilateral agreements by the judicature or actually termination of the agreements in that regard.

There is also a practical question about the possibility of issuing a European Certificate of Succession (ECS) in a case in which a Polish court uses a bilateral agreement as the ground of its jurisdiction. Obviously none of the agreements excludes the admissibility of issuance of ECS. Therefore the overwhelming opinion is that since Polish courts may issue a decision based on its jurisdiction determined under a bilateral agreement, it is also possible to issue ECS. The wording of the Regulation itself is, however, problematic. Under Article 64 of Regulation (EU) No 650/2012, ECS may be issued in the Member State whose courts have jurisdiction under Article 4, Article 7, Article 10, or Article 11 of the Regulation. Therefore, the wording of the provision excludes the issuance of ECS in a situation where jurisdiction is governed by the provisions of a bilateral agreement that has a priority. However, as rightly noted in the doctrine, the said provision is not to ground jurisdiction in the provisions listed therein but rather to make the issuance of ECS dependent on the existence of such jurisdiction. If jurisdiction in fact exists, then even if it arises, in whole or in part, from provisions other than the listed ones, there is no reason to exclude the issuance of ECS and refer the parties concerned only to national courts for succession proceedings ${ }^{26}$. However, that issue gives rise to a number of concerns.

${ }^{26}$ M. Margonski, in: Rozporzqdzenie..., comment 25 on Article 75; A. Dutta: Münchener op. cit., bibliographic note 9 . 


\section{Conclusions}

Concluding, it may be stated that there are many practical concerns regarding the existence, under Article 75.1 of Regulation (EU) No 650/2012, of bilateral agreements on legal assistance regulating national jurisdiction, recognition and enforcement of decisions. While they are not as frequent as complications relating to the conflict-of-laws rules (of applicable law), they do disturb the uniform application of the Succession Regulation in procedural terms.

Most significantly, the complications arise when procedural rules arising from a bilateral agreement are to be respected by courts of other Member States that are not bound by a given agreement. There are doubts as whether or not there is a legal basis for that.

Furthermore, it leads to the implementation of procedural connecting factors in the European legal area, such as nationality or location or immovable property, that Regulation (EU) No 650/2012 attempted to eliminate or limit. It defeats the purpose of the Regulation which was to create a unity of forum for succession matters.

Therefore, the requests for renegotiation of the agreements to some extent, (though not their termination altogether) are worth considering ${ }^{27}$. There is, however, hardly any requirement for Member States to terminate such agreements under EU law. The need for renegotiation is rather dictated by practical reasons and the need to ensure uniform nature of the legal system.

It is also necessary to arrive at an interpretation of the agreements' provision that does not excessively expand the scope of their application. They should not be interpreted according to the principle that if something is not envisaged by law, then it is forbidden. The assumption should be quite the opposite. It is also worth keeping in mind that the same agreement is applied in a third state and is meant for the protection of Polish citizens' rights in that country.

${ }^{27}$ Cf. R. Frimston: European Union Succession Regulation..., p. 199. See also A. Dutta: The Perspective of the European Union. In: European Private International Law and Member State Treaties with Third States. The Case of the European Succession Regulation. Eds. A. Dutta, W. Wurmnest. Intersentia 2019, p. 323. 


\section{References}

Bonomi A.: Le droit des successions. Commentaire du Reglement (UE) no 650/2012 du 4 julliet 2012. Bruylant 2016.

Calliess Ch., Ruffert M. (eds.): EUV/EGV. Das Verfassungsrecht der Europäischen Union mit Europäischer Grundrechtecharta. Kommentar. München 2007.

Czepelak M.: Umowa międzynarodowa jako źródto prawa prywatnego międzynarodowego. Warszawa 2008.

Czubik P.: Obowiazywanie norm kolizyjnych z umów o pomocy prawnej zawartych z Biatorusia, Ukraina $i$ Rosja $w$ obrębie materii objętej zakresem zastosowania rozporzadzeń europejskich. „Nowy Przegląd Notarialny” 2015, No. 3.

Dutta A.: Münchener Kommentar, Vol. 10 (ed. J. v. Hein), Article 64 of Regulation (EU) No 650/2012, Article 64 of Regulation (EU) No 650/2012.

Dutta A.: The Perspective of the European Union. In: European Private International Law and Member State Treaties with Third States. The Case of the European Succession Regulation. Eds. A. Dutta, W. Wurmnest. Intersentia, 2019.

Frimston R.: European Union Succession Regulation 650/2012: an update end entreaty. "Private Client Business" 2018, vol. 6.

Geiger R., Khan D.-E., Kotzur M. (eds.): EUV/AEUV. Vertrag über die Europäische Union und Vertrag über die Arbeitsweise der Europäischen Union. Kommentar. München 2010.

Grzebyk P.: Jurysdykcja krajowa $w$ sprawach z zakresu prawa pracy $w$ świetle rozporzadzenia Rady (WE) nr 44/2001. Warszawa 2011.

Grzegorczyk P.: Jurysdykcja krajowa w sprawach z zakresu prawa własności przemystowej. Warszawa 2007.

Kohler Ch.: Die künftige Erbrechtsverordnung der Europäischen Union und die Staatsverträge mit Drittstaaten. In: Europäisches Erbrecht. Zum Verordnungsvorschlag der Europäischen Kommission zum Erb- und Testamentsrecht. Eds. G. Reichelt, W.H. Rechberger, 2011.

Lenz C.-O., Borchardt K.-D.: EU-Verträge. Kommentar nach dem Vertrag von Lissabon. Köln-Wien 2010.

Magnus U., Mankowski P. (eds.): Brussels I Regulation. Sellier 2007.

Nuyts A.: Study of Residual Jurisdiction: Review of the Member States' Rules concerning the 'Residual Jurisdiction' of their courts in Civil and Commercial Matters pursuant to the Brussels I and II Regulations'. Available online: EC, https://gavclaw.files.wordpress.com/2020/05/arnaud-nuyts-study_resi dual_jurisdiction_en.pdf (accessed 13.10.2020).

Pazdan M.: Zakres zastosowania rozporzadzenia spadkowego. In: Nowe europejskie prawo spadkowe. Eds. M. Pazdan, J. Górecki. Warszawa 2015.

Rozporzadzenie Parlamentu Europejskiego $i$ Rady (UE) Nr 650/2012 z dnia 4 lipca 2012 r. $w$ sprawie jurysdykcji, prawa właściwego, uznawania $i$ wyko- 
nywania orzeczeń, przyjmowania $i$ wykonywania dokumentów urzędowych dotyczacych dziedziczenia oraz $w$ sprawie ustanowienia europejskiego poświadczenia spadkowego. Komentarz. Ed. K. Os ajd a. Warszawa 2020.

Szpunar M., Pacuła K.: Prawo prywatne międzynarodowe. Komentarz. Ed. M. Pazdan. Warszawa 2019. 